\title{
Study on Relationship of the RMB Internationalization, Cross-border Trade Settlement and Capital Account Liberalization
}

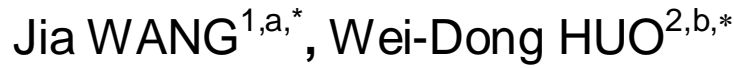 \\ ${ }^{1}$ Southwestern University of finance and economics, Chengdu 611130, China \\ ${ }^{2}$ Southwestern University of finance and economics, Chengdu 611130, China \\ a24881588@qq.com, ${ }^{\mathrm{b}}$ horsehwd@foxmail.com \\ ${ }^{*}$ Corresponding author
}

Keywords: RMB internationalization, cross-border trade settlement, capital account liberalization

\begin{abstract}
With the fast development of economic globalization, RMB internationalization is becoming a major issue .Since 2009 The State Council announced the policy of RMB settlement of cross-border trade, RMB internationalization has achieved a substantive stage of development. When we analyze the cross-border RMB settlement and RMB internationalization, we should also research on the issue of liberalization the capital account. This paper describes the situation of the RMB international, cross-boarder trade settlement and capital account liberalization, combined with relevant theoretical research, which seeks to draw the interaction mechanism among the three. Finally, this paper provides suggestions and measures about how to expand the cross-border trade RMB settlement, open capital account sequentially and promote RMB internationalization.
\end{abstract}

\section{The literature review of RMB internationalization, cross-boarder trade settlement and capital account liberalization}

Tavals(1997) argues that currency internationalization consists three conditions: the confidence of country's political stability, the currency country has a deep and liberalization financial markets, the export volume accounted for a large proportion of the world. Kenen(1996) divides money into two levels of official and private, clearly defines the specific functions of an international currency. Ba Shusong(2008) pointed out that before the RMB fully convertible, should be based on the cross-border trade, and promote the RMB regionalization. Zhang Liqing (2009) points out that the full convertibility of the currency is the most basic foundation of a country's currency as an international currency. Zhao Kuanghai(2003) believes that during the courses of currency internationalization, the relationship between the Currency convertibility and currency internationalization is very closely, but in the initial stage of an international currency ,the currency is not fully meet the conditions of full convertibility.

\footnotetext{
* This paper was financially supported by strategy of free trade zone and research on RMB area (scientific research and innovation team of Sichuan colleges and universities; leader: Wei-dong Huo; project number: JBK130504)
} 


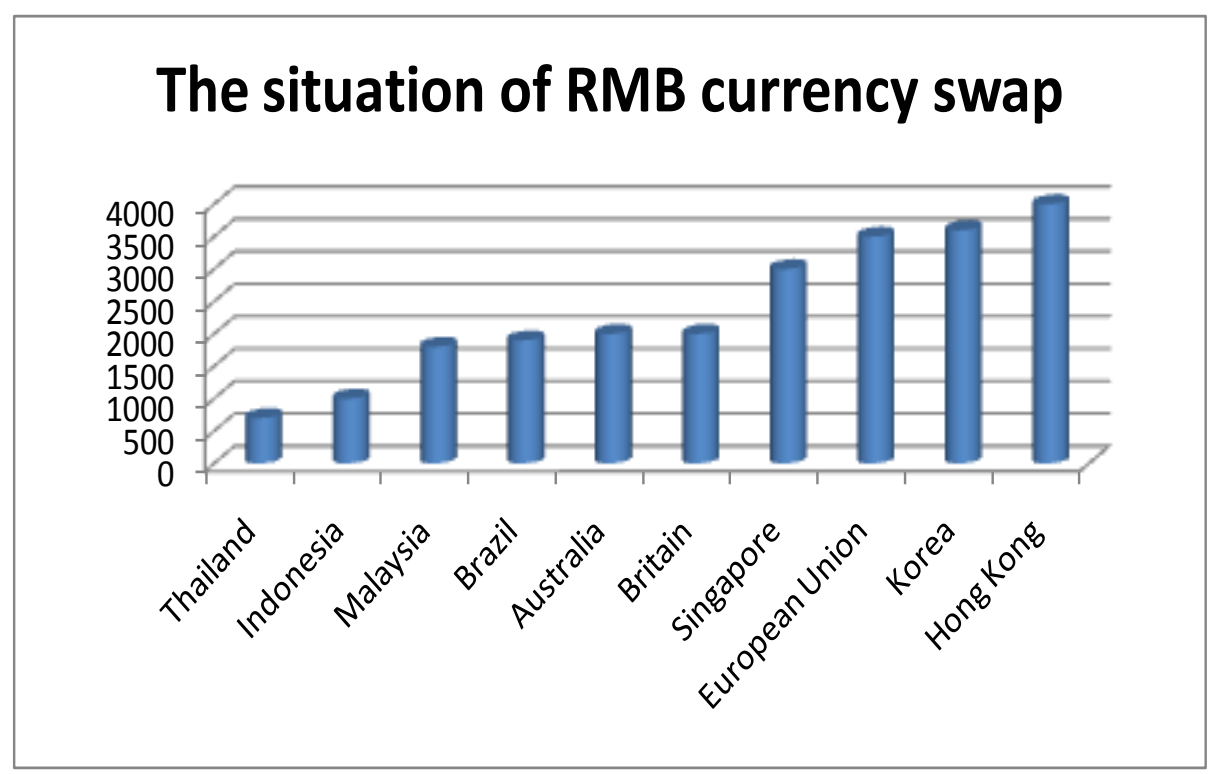

Fig. 1 the situation of RMB currency swap

Data Sources: People's Bank of China

Unit: one hundred million Yuan

In recent five years, the people's bank of China successively signed the bilateral currency swap agreements that is worth of a total of 2.8127 trillion RMB with other central Banks and monetary authorities, among which the amount more than 200 billion RMB includes the reserve bank of Australia, the European central bank, the bank of England and the bank of Korea, Hong Kong monetary authority, the monetary authority of Singapore.

Currency swaps can provide countries with liquidity, servicing as a kind of standby credit arrangement. Using local currency swap indicted that the RMB in international recognition is increasing day by day. When the RMB is more and more widely used, International foreign exchange market can produce the demand for currency swap. In addition, currency swaps can also promote the importance of RMB in the international monetary system.

From the Fig.2, we can see clear that since the beginning of April 2009, the RMB settlement of cross-border trade has been developing rapidly. From 58.7 billion Yuan in 2009 to 4.63 trillion Yuan in 2013, compound annual growth rate is 123.6\%. In particular, in the year of 2011 the State Council announced a policy that the cross-border RMB trade settlement area can be extended to the territory of the country, cross-border RMB trade settlement presents a blowout situation.

The meaning of the cross-border RMB settlement is as follows: Firstly, cross-border RMB trade settlement will help enterprises avoid exchange rate risk effectively, speeding up the convenience of the settlement, improving the service efficiency of funds. Secondly, When the RMB has increasingly become the international settlement, cross-border RMB trade settlement can promote the status of RMB, gradually changing with the dollar as the center of the international monetary system. 


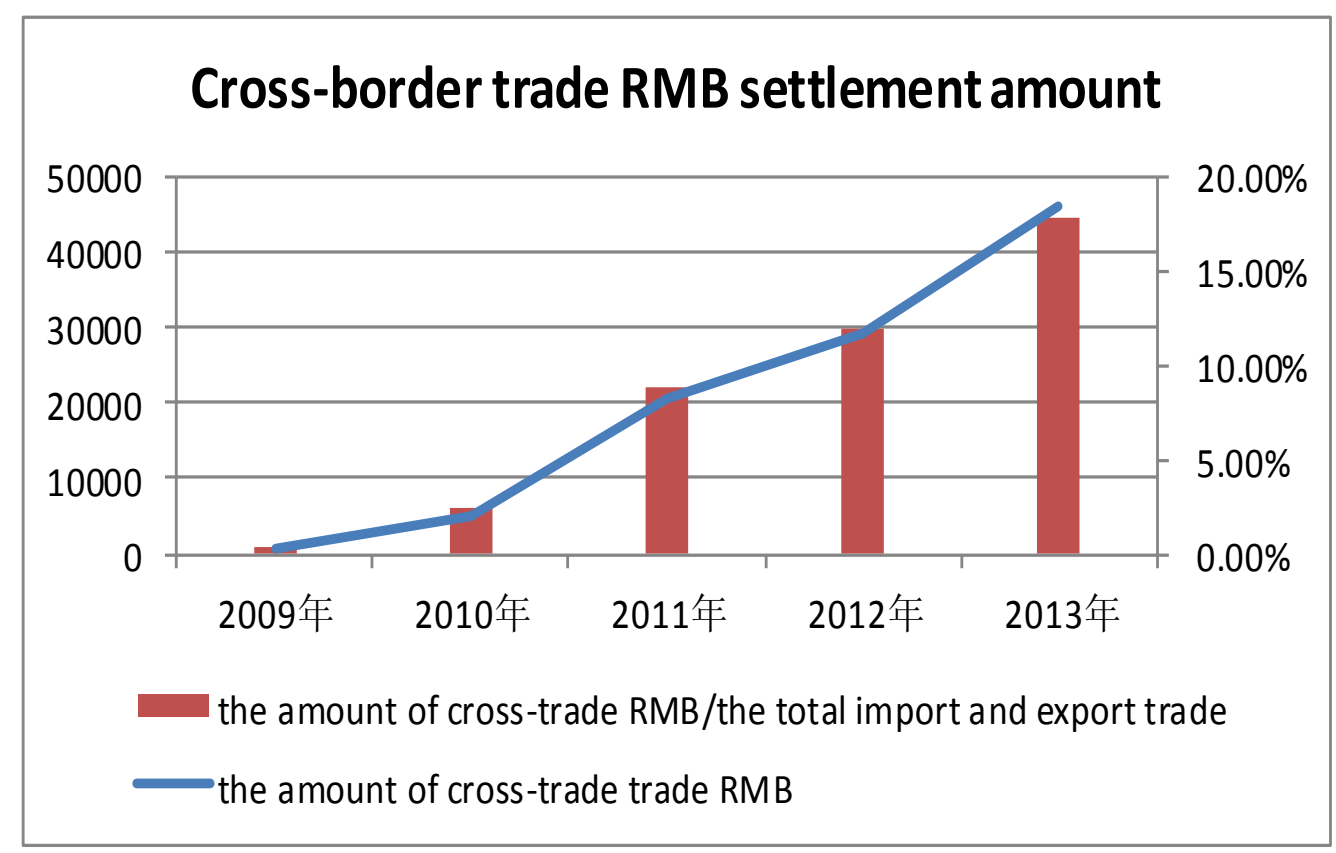

Fig. 2 the situation of Cross-border trade RMB settlement

Data Sources: People's Bank of China

Unit: one hundred million Yuan

\section{Content of cross-border RMB trade settlement}

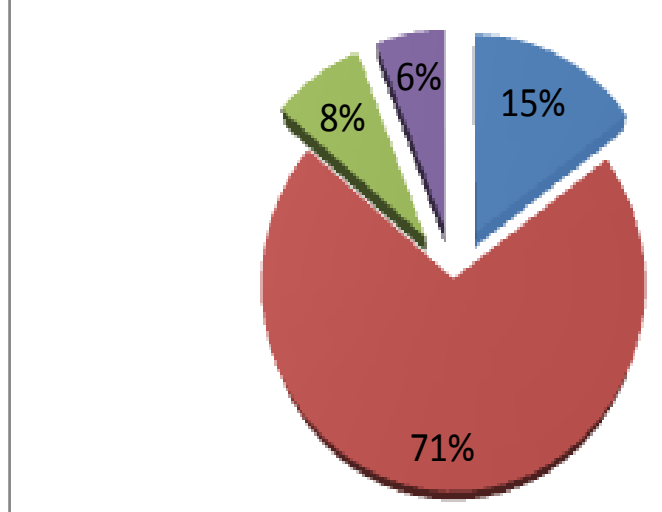

Exports of goods trade

- Imports of goods trade

Settlement of services and other Current

Account

Capital and Financial

Account

Fig. 3 the content of cross-border RMB trade settlement

Data Sources: The report of China International Payment Presentation, 2012

By analyzing the Fig.3, we suggest that in the term of the proportion of cross-border RMB trade settlement, the total amount of cross-border Yuan trade settlement accounts for a small proportion of import and export trade volume, only $18.52 \%$ in 2013. As for the formation of the cross-border RMB trade settlement, import of goods accounted for the proportion of cross-border RMB trade settlement is $71 \%$. According to the 2013 China international balance report, in the year of 2013 , Cross-border RMB trade settlement account for current account transactions account $94 \%$, by 
contrast, the proportion of capital account is very low.

According to the classification standards of IMF "annual report on exchange arrangements and exchange restrictions, 2013", China has 14 basic convertibility projects which account for 35\%, mainly concentrated in Commercial credit, financial credit, direct investment, liquidation of direct investment. There are 22 partially convertible projects, mainly including bond market trading, stock market trading, and the trading of real estate as well as personal capital, which account for $55 \%$. Inconvertibility under the status of capital items has 22, mainly including the residents to participate in the domestic market and money market as well as fund trust trading derivatives, accounting for $10 \%$.

\section{The Mechanism Analysis of RMB internationalization, cross-boarder trade settlement and capital account liberalization}

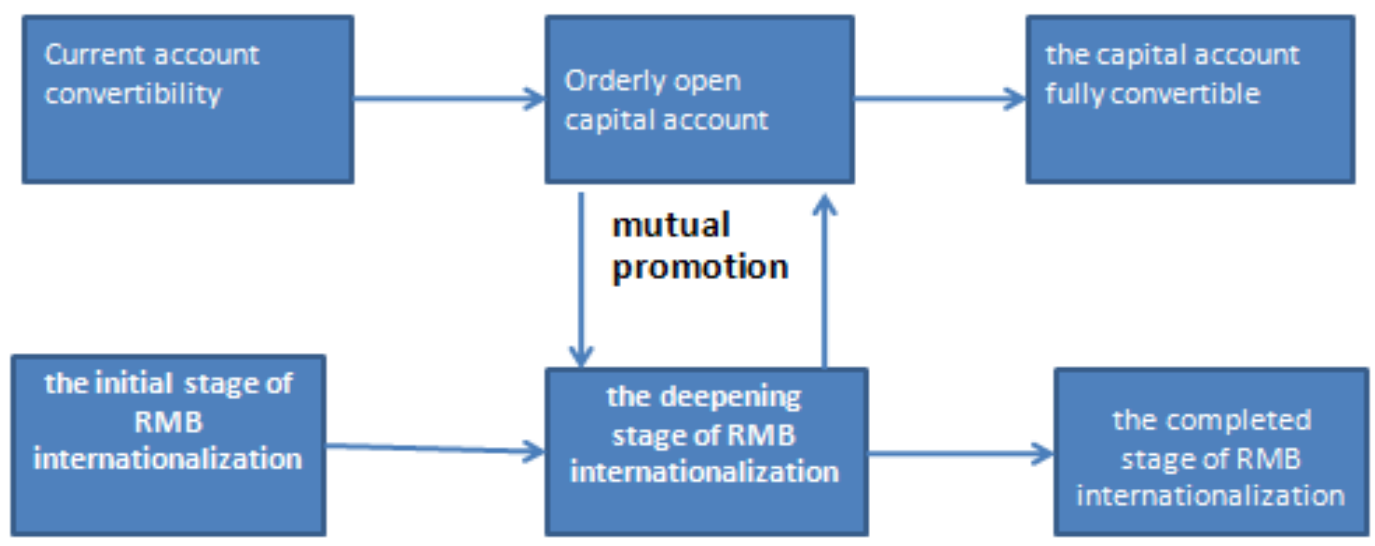

The function of valuation and settlement
The function of investment and trading
The function of reserving

Fig.4 the relationship between the capital account and the internationalization of RMB

The internationalization of RMB actually refers to a process that currency capital functions expend from the original applicable area expanded to the surrounding area even to the world. The evolution of RMB internationalization means that the currency has the function of international valuation, settlement, investment as well as reserving. The core meaning of RMB internationalization is that $\mathrm{RMB}$ have a basic function of convertibility .Only when the capital account liberalization is available in the world, can foreign residents and the financial institutions hold and use the RMB freely, as a means of the pricing and trading of various financial products investment. The RMB current goal is to expand the cross-border trade and cross-border investment. So the RMB cross-border settlement function should no longer be confined to cross-border trading but gradually expand to the capital account. The realization of the convertibility of capital account lays function of trading to investment, even reserving. If the government wishes to realize RMB internationalization through capital account inconvertibility, which is not a feasible plan.

It is important to emphasize that the advancement of the internationalization of RMB is not necessarily on the premise of full convertibility of capital account. If RMB acts as the international currency in the future, the long-term control of capital account is bound to restrict the process of RMB internationalization. 
Backflow channels (Offshore financial center, QFII, RMB currency swap)

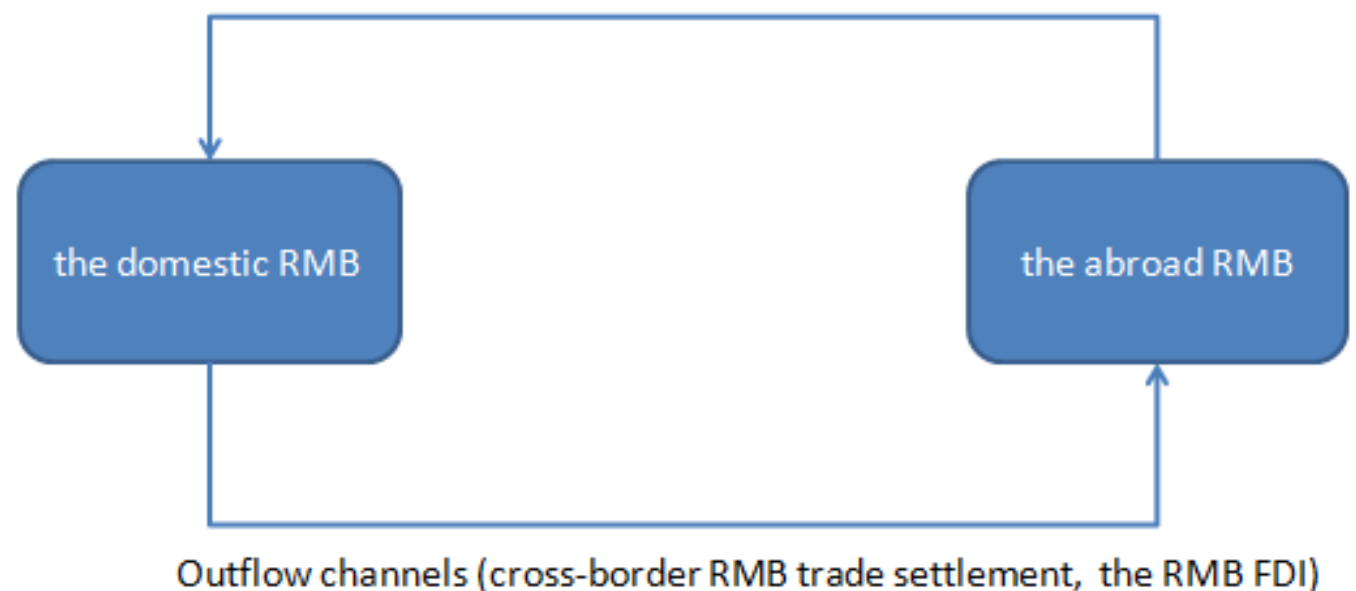

Fig. 5 the relationship between the capital account and the cross-border RMB trade settlement

In 2012, the World Bank published the "China 2030" put forward that the RMB internationalization depends on the speed of China's financial reform and the capital account liberalization. When the RMB internationalization is promoted step by step, on one hand it requires capital account convertibility, on the other hand it calls for capital account continuous liberalization. So capital account convertibility and the internationalization of the RMB promote each other, providing the conditions for their development. So capital account convertibility promotes the internationalization of RMB, providing the conditions for its development.

A complete cross-border RMB trade settlement includes the course of RMB circulation from China to the overseas, and the backflow from abroad to China. If the RMB backflow is unavailable, the RMB cross-border circulation channels can't be established, which will hinder the progress of cross-border RMB settlement.

Promoting capital account convertibility and liberalization gradually that previously restricts foreign direct investment, equity investment, debt securities investment, which is directly related to the free flow of capital. On one hand capital account convertibility can expand the outflow channel, on the other hand it can fundamentally solve the problem of overseas RMB backflow channels, providing a smooth circulation channel for cross-border RMB trade settlement. Capital account liberalization can fundamentally solve the problem of offshore RMB investment and backflow channels. In terms of risk control, Capital account liberalization plays a pivotal role in dealing with the problem of RMB backflow and enhancement of cross-border RMB trade settlement.

According to practical experience of currency internationalization, the path of RMB internationalization is usually divided into two categories: from the perspective of development direction of international currency, almost all countries follow the "peripheral-regionalization-

globalization" route; in addition, in terms of evolution of main function of international currency, most countries go through the course of "currency settlement-pricing units-value reserving", therefore, RMB will get deepening in currency function and not remain as the settlement currency.

Regardless of any way mentioned above, cross-border RMB trade settlement plays an important role in $\mathrm{RMB}$ internationalization. So the cross-border RMB trade settlement is the founding of RMB internationalization. With the development of cross-border RMB trade settlement, RMB internationalization has achieved a substantive progress. 


\section{Conclusion}

The development of cross-border RMB trade settlement has a momentous implication for RMB internationalization. Moreover, capital account liberalization and reform is the intrinsic demand and driving force for RMB internationalization. Excessive capital controls go against the development of domestic capital market and hinder the RMB internationalization. As a matter of fact, RMB internationalization to a certain extent is also the process of deepening development of cross-border RMB trade settlement and capital account liberalization.

\section{References}

[1].George S, Tavlas, Internationalization of currencies: the case of the US dollar and its challenger euro [J].The International Executive.1997 (9):581-597

[2].Chinn, Menzie and Jeffrey A. Frankel.Why the Euro will Rival the Dollar [J].International Finance.2008 (5):49-73

[3].Kenen, Peter. The Role of the Dollar as an International Currency [J].Eastern Economic Journal, Vol.22, 1996(2):127-136.

[4].Ba Shusong, Wu Bo.The influence of RMB internationalization on China's financial sector development [J]. Southwest of financial, 2008(4):4-8.

[5].Zhang Liqing. Towards the International sage of Renminbi Status quo and Prospect [J]. Journal of central university of finance and economics, 2009(10):24-28.

[6].Zhao Haikuan.RMB Is Capable of Becoming One of the World Currencies [J].Economic research January. 2003(3):54-60.

[7].Eichengreen, Barry. The Renminbi as an International Currency [J].Journal of Policy Modeling, 2011, 33(5):723-730.

[8].Robert McCauley. The Internationalization of the Renminbi[R].Bank of International Settlement, 2011, 14, January.

[9].Prasad, Eswar and LeiYe.The Renminbi's Role in the Global Monetary System[R].IZA Discussion Paper, 2012, No.6335.

[10].Barry Eichengreen. The renminbi as an international currency [J].Journal of Policy Modeling.2011 (7):723-730 